\title{
Analisis Kinerja Keuangan Perhotelan Akibat Pandemi Covid-19
}

\author{
Andi Ayu Frihatni ${ }^{1}$, Irmayanti Sudirman², Frengky Mandacan ${ }^{3}$ \\ ${ }^{1}$ IAIN Parepare, ${ }^{2}$ STIE AMSIR Parepare \\ ${ }^{3}$ Badan Keuangan dan Aset Daerah Manokwari Selatan \\ Email korespondensi: andiayufrihatni@iainpare.ac.id
}

\begin{abstract}
This research aims to prove the impact of pandemic of COVID-19 on magnitude of the decline of financial performances before and along pandemic of COVID-19. The type of this research is descriptive quantitative conducted at Parepare South Sulawesi. The sample of the research was all hotels in Parepare of 25 hotels. Data regarding revenue statement were analyzed comparatively in this research. The result of this research found that the level of the decline of revenues of hotels due to the pandemic of COVID-19 has the value between 13\%-49\%. However, the pandemic of COVID-19 really affects the decline of revenues gained by the hotel sector in Parepare. The result of this research contributes to the impact of the pandemic affecting the hotel sector in the regional. It becomes empirical evidence that financial performances in hotel suffers the decline compared to prior period
\end{abstract}

Keywords: Hotel, Pandemic of COVID-19, Performance, Revenue

\begin{abstract}
Abstrak. Penelitian ini bertujuan untuk menganalisis dampak pandemi COVID-19 terhadap kinerja keuangan perhotelan sebelum dan selama pandemi COVID-19. Jenis penelitian ini adalah kuantitatif deskriptif yang dilakukan di Parepare Sulawesi Selatan. Sampel penelitian adalah seluruh hotel di Parepare sebanyak 25 hotel. Data laporan pendapatan dianalisis secara komparatif. Temuan hasil penelitian ini adalah adanya penurunan pendapatan hotel akibat pandemi COVID-19 yang berada di kisaran 13\%-49\%. Hasil penelitian ini berkontribusi terhadap dampak pandemi yang mempengaruhi sektor perhotelan di daerah. Ini menjadi bukti empiris bahwa kinerja keuangan sektor jasa perhotelan mengalami penurunan dibandingkan dengan tahun sebelumnya
\end{abstract}

Kata Kunci: Hotel, Pandemi COVID-19, Kinerja, Pendapatan

\section{PENDAHULUAN}

Hotel merupakan salah satu industri sektor jasa bidang kepariwisataan, keberadaan hotel semakin penting untuk masyarakat, karena hotel menyediakan sarana dan pelayanan bagi para pelanggannya. Jasa- jasa yang dapat ditawarkan dalam bidang perhotelan, diantaranya fasilitas penyediaan/penyewaan kamar, fasilitas penyediaan ruang konferensi dan sebagainya. Pada dasarnya, jasa pelayanan hotel sudah dinikmati pada saat melakukan registrasi, ketika menginap di kamar, makan dan minum di restoran, atau ketika tamu tersebut mengikuti acara seminar, rapat dan kegiatan lainnya. Hotel merupakan salah satu bentuk jasa karena pelayanan hotel tidak berwujud dan tidak mengakibatkan kepemilikan sesuatu. Meningkatnya persaingan antar hotel menyebabkan masing-masing hotel berusaha memberikan kualitas dan jasa yang terbaik kepada pelanggannya.

Melihat adanya peluang yang baik dan dapat dimanfaatkan dalam bidang pariwisata, maka banyak perusahaan yang berminat melakukan usaha dibidang jasa penginapan dan mewujudkannya melalui pendirian bermacammacam hotel, mulai dari hotel yang mewah sampai dengan penginapan biasa. Hal ini dapat di buktikan dengan melihat Parepare merupakan salah satu kota terbaik di Indonesia yang meraih penghargaan kategori Apresiasi Smart Branding. Tentunya, Parepare merupakan kota transit dimana pengunjung biasanya dari arah Makassar yang ingin melakukan wisata ke arah Toraja, pasti melewati kota Parepare, atau pengunjung yang hanya ingin melakukan perjalanan dinas kerja di Parepare. Begitupun sebaliknya pengunjung dari arah Toraja, Enrekang, Pinrang, Sidrap yang ingin berwisata atau melakukan perjalanan dinas kerja ke kota Makassar pasti melewati kota Parepare.

Sektor perhotelan adalah segmen penting dari industri pariwisata dan kontribusi terhadap pertumbuhan ekonomi beberapa destinasi. Kinerja dan efektivitas organisasi hotel sangat tergantung pada pengetahuan dan kemampuan karyawan (sumber daya manusia), pengetahuan organisasi (modal struktural yang sebagian besar terdiri dari sistem/rutinitas hotel) dan pada modal relasional dan pelanggannya. Hal inilah yang 
dimanfaatkan oleh Pemerintah khsusnya disektor pariwisata atau perhotelan sebagai sumber pendapatan asli daerah dari Kota Parepare. Sesuai dengan data yang diperoleh dari pendapatan daerah Parepare yang paling besar pendapatannya yaitu dari sektor perhotelan di Parepare. Hal ni dikarenakan tiap tahunnya pembayaran pajak perhotelan yang masuk ke kas daerah yaitu dari perhotelan di Parepare merupakan pajak yang tertinggi dibanding dengan sektor usaha lainnya yang ada di Parepapare.

Kinerja adalah kemampuan kerja yang telah tercapai (Purnamasari dkk., 2020). Sedangkan kinerja keuangan (Muslich, 2013) adalah prestasi keuangan yang tergambar dalam laporan keuangan perusahaan yaitu neraca rugilaba dan kinerja keuangan menggambarkan usaha perusahaan (operation income). Profitability suatu perusahaan dapat diukur dengan menghubungkan keuntungan yang diperoleh dari kegiatan pokok perusahaan dengan kekayaan aset yang digunakan untuk menghasilkan keuntungan. Riyanto (2011) menyatakan bahwa kemampuan perusahaan di bidang keuangan dapat memberikan informasi tentang aliran dana. Penilaian kinerja keuangan dapat menginformasikan kondisi keuangan suatu perusahaan dalam keadaan baik maupun tidak. Selain itu penilaian kinerja keuangan sangat penting bagi manajer untuk mengambil kebijakan dan strategi ke depannya. Pada dasarnya penilaian kinerja keuangan setiap perusahaan berbeda-beda, bisa dengan membandingkan dari tahun-tahun sebelumnya atau membandingkan dengan standar industri yang sejenis.

Dampak pandemi COVID-19 dialami oleh sebagian besar bisnis (Abbas \& Frihatni, 2020). Kinerja keuangan bisnis selama pandemi Covid19 mengalami penurunan di berbagai sektor (Esomar, 2021; Lowardi \& Ardi, 2021; Muhari, 2021; Sullivan \& Widoatmojo, 2021). Pada sektor UMKM, pendapatannya pun mengalami penurunan (Martalina, 2021; Yuliana, 2020). Perhotelan adalah salah satu sektor bisnis yang tentunya mengalami penurunan pelanggan. Berbeda halnya dengan penelitian sebelumnya yang cenderung menyoroti penurunan kinerja pada sektor perusahaan publik dan UMKM.
Penelitian ini bertujuan untuk mengetahui dampak kinerja keuangan yang dialami oleh sektor perhotelan. Di kota Parepare, sektor perhotelan adalah bisnis yang mendukung pendapatan asli daerah. Saat Covid terjadi di awal tahun 2020 pendapatan hotel di Parepare mengalami penurunan. Hal ini disebabkan adanya kebijakan dari pemerintah untuk melakukan penutupan sementara semua hotel di Parepare. Dengan kebijakan dari pemerintah kepada seluruh hotel yang ada di Parepare diberi keringanan tidak membayar pajak hotel selama 3 bulan pada awal tahun 2020 atau pada saat awal virus COVID-19. Adanya larangan berwisata ke daerah manapun termasuk ke Parepare dan pembatasan beberapa bulan mengakibatkan sector perhotelan ditutup sehingga berpengaruh terhadap kinerja keuangannya. Selama pandemi, jasa perhotelan memungkinkan mengalami penurunan pendapatan sehingga penelitian ini bertujuan untuk menganalisis kinerja keuangan sektor perhotelan selama setahun akibat adanya pandemi Covid-19 dan membandingkannya dengan kinerja keuangan sebelum pandemi. Dengan demikian, temuan penelitian ini bisa menjadi bukti empiris bahwa kinerja keuangan sektor jasa perhotelan mengalami penurunan drastis dibandingkan dengan tahun sebelumnya.

\section{METODE PENELITIAN}

Jenis penelitian ini adalah kuantitatif deskriptif. Penelitian kuantitatif deskriptif dilakukan dengan cara menggambarkan dan menganalisis data yang sudah diolah secara statistik deskriptif. Populasi penelitian adalah seluruh sektor hotel yang ada di Parepare. Pengambilan sampel dalam penelitian ini dilakukan di Kota Parepare Sulawesi Selatan. Jumlah sampel adalah seluruh hotel di Parepare sebanyak 25 hotel. Sampling jenuh dijadikan sampel di mana seluruh sektor perhotelan yang berada di Parepare yang berjumlah 25 hotel dijadikan sampel penelitian. Data penelitian ini merupakan data sekunder dan bersumber dari pendapatan hotel pada tahun 2019 dan 2020. Analisis komparatif pendapatan hotel sebelum dan selama pandemi digunakan dalam penelitian ini. 


\section{HASIL DAN PEMBAHASAN}

Ada 25 hotel di kota Parepare. Jumlah pendapatan pada tahun 2019 dam 2020 disajikan pada tabel dibawah ini.

Tabel 1. Pendapatan Sebelum dan Selama Pandemi COVID-19

\begin{tabular}{|c|c|c|c|}
\hline No. & NAMA HOTEL & $\begin{array}{c}\text { SEBELUM } \\
\text { PANDEMI } \\
2019 \\
\text { (JUTAAN) }\end{array}$ & $\begin{array}{c}\text { SELAMA } \\
\text { PANDEMI } \\
2020 \\
\text { (JUTAAN) }\end{array}$ \\
\hline 1) & GRAND STAR & Rp. 1.220 & Rp. 870 \\
\hline 2) & GRAND KARTIKA & Rp. 1.080 & Rp. 760 \\
\hline 3) & FORTUNA & Rp. 840 & Rp. 720 \\
\hline 4) & LOTUS & Rp. 1.020 & Rp. 820 \\
\hline 5) & BUKIT KENARI & Rp. 1.440 & Rp. 900 \\
\hline 6) & SATRIA WISATA & Rp. 1.500 & Rp. 920 \\
\hline 7) & PARE BEACH & Rp. 960 & Rp. 780 \\
\hline 8) & HOTEL 88 & Rp. 980 & Rp. 800 \\
\hline 9) & PARIWISATA & Rp. 1.140 & Rp. 870 \\
\hline 10) & GAZZAS & Rp. 780 & Rp. 660 \\
\hline 11) & MIRANDA & Rp. 660 & Rp. 540 \\
\hline 12) & HOTEL BUGIS & Rp. 1.060 & Rp. 730 \\
\hline 13) & YOUTEFA & Rp. 720 & Rp. 410 \\
\hline 14) & DELIMA SARI & Rp. 1.600 & Rp. 1.080 \\
\hline 15) & PERMATA SARI & Rp. 1.500 & Rp. 920 \\
\hline 16) & KUMALA SARI & Rp. 840 & Rp. 730 \\
\hline 17) & HOTEL MARIO & Rp. 540 & Rp. 310 \\
\hline 18) & DENPASAR & Rp. 580 & Rp. 330 \\
\hline 19) & HOTEL GRAHA & Rp. 1.100 & Rp. 560 \\
\hline 20) & PURI GANDARIA & Rp. 730 & Rp. 420 \\
\hline 21) & GANDARIA 1 & Rp. 700 & Rp. 400 \\
\hline 22) & GANDARIA 2 & Rp. 720 & Rp. 410 \\
\hline 23) & HOTEL RICH & Rp. 800 & Rp. 430 \\
\hline 24) & PLATINUM & Rp. 810 & Rp. 420. \\
\hline 25) & SRIWIJAYA & Rp. 780 & Rp. 450. \\
\hline \multicolumn{2}{|r|}{ RATA-RATA } & RP. 964 & Rp. 649 \\
\hline
\end{tabular}

Rata-rata pendapatan hotel di Kota Parepare menghasilkan Rp 964.000. Pendapatan hotel setahun sebelum pandemi COVID-19 (2019) menunjukkan kisaran Rp 540.000-Rp 1.600.000.000. Pendapatan tertinggi dihasilkan oleh Hotel Delima Sari sebesar Rp 1.600.000.000, sedangkan pendapatan terendah dihasilkan oleh Hotel Mario sebesar Rp 540.000. Setahun kemudian pada tahun 2020, terjadi pandemi sehingga semua Hotel mengalami penurunan pendapatan yang cukup drastis.
Berikut jumlah penurunan pendapatan setiap hotel disajikan pada tabel di bawah ini.

Tabel 2. Jumlah Penurunan Pendapatan

\begin{tabular}{|c|l|c|c|}
\hline NO. & \multicolumn{1}{|c|}{ NAMA } & $\begin{array}{c}\text { PENURUNAN } \\
\text { (JUTAAN) }\end{array}$ & PERSENTASE \\
\hline 1 & GRAND STAR & Rp350 & $29 \%$ \\
\hline 2 & GRAND KARTIKA & Rp320 & $30 \%$ \\
\hline 3 & FORTUNA & Rp120 & $14 \%$ \\
\hline 4 & LOTUS & Rp200 & $20 \%$ \\
\hline 5 & BUKIT KENARI & Rp540 & $38 \%$ \\
\hline 6 & SATRIA WISATA & Rp580 & $39 \%$ \\
\hline 7 & PARE BEACH & Rp180 & $19 \%$ \\
\hline 8 & HOTEL 88 & Rp180 & $18 \%$ \\
\hline 9 & PARIWISATA & Rp270 & $24 \%$ \\
\hline 10 & GAZZAS & Rp120 & $15 \%$ \\
\hline 11 & MIRANDA & Rp120 & $18 \%$ \\
\hline 12 & HOTEL BUGIS & Rp330 & $31 \%$ \\
\hline 13 & YOUTEFA & Rp310 & $43 \%$ \\
\hline 14 & DELIMA SARI & Rp520 & $33 \%$ \\
\hline 15 & PERMATA SARI & Rp580 & $39 \%$ \\
\hline 16 & KUMALA SARI & Rp110 & $13 \%$ \\
\hline 17 & HOTEL MARIO & Rp230 & $43 \%$ \\
\hline 18 & DENPASAR & Rp250 & $43 \%$ \\
\hline 19 & HOTEL GRAHA & Rp540 & $49 \%$ \\
\hline 20 & PURI GANDARIA & Rp310 & $42 \%$ \\
\hline 21 & GANDARIA 1 & Rp300 & $43 \%$ \\
\hline 22 & GANDARIA 2 & Rp310 & $43 \%$ \\
\hline 23 & HOTEL RICH & Rp370 & $46 \%$ \\
\hline 25 & PLATINUM & Rp390 & $48 \%$ \\
\hline
\end{tabular}

Berdasarkan Tabel 2, rata-rata penurunan hotel selama pandemi sebesar Rp 314.000.000 dengan level penurunan 33\%. Adanya penurunan pendapatan selama pandemi disebabkan karena PSBB dilakukan di Parepare, diberlakukan Work from Home, dan ditutupnya pada waktu itu akses berwisata.

\section{KESIMPULAN}

Rata-rata pendapatan hotel di Kota Parepare menghasilkan Rp 964.000.000 sebelum pandemi pada tahun 2019, tetapi selama pandemi pada tahun 2020, pendapatan Hotel mengalami penurunan dengan rata-rata sebesar $\mathrm{Rp}$ 649.600.000. Penelitian ini membuktikan bahwa sektor jasa perhotelan mengalami penurunan selama pandemi berada di kisaran 13\%-49\%. 
COVID-19 sangat berdampak pada penurunan kinerja keuangan di sektor perhotelan di Parepare. Kondisi ini tidak bisa dihindarkan bahwa kebijakan pemerintah daerah setempat dengan melakukan penutupan tempat wisata dan pembatasan aktivitas mengakibatkan besaran pendapatan hotel menurun.

\section{SARAN}

Keterbatasan dalam penelitian ini adalah data keuangan mengenai biaya operasional dan administrasi hotel yang dapat mempengaruhi jumlah pendapatan, tidak dapat diakses. Sebab selama pandemi, pihak manajemen hotel berupaya membayar gaji karyawan dan mengeluarkan biaya operasional dan administrasi lainnya yang dapat mengurangi keuntungan yang diperoleh perhotelan. Dengan demikian, penelitian lanjutan diharapkan menganalisis profitabilitas perhotelan dengan mengidentifikasi pendapatan dan beban.

\section{DAFTAR PUSTAKA}

Abbas, A., \& Frihatni, A.A. (2020). The Social Role of Islamic Banks in Indonesia during the Pandemic of COVID-19: Reflection of Market Share. Growth, 2020.

Esomar, M. (2021). Analisis Dampak COVID-19 terhadap Kinerja Keuangan Perusahaan Pembiayaan di Indonesia. Jurnal Bisnis, Manajemen, dan Ekonomi, 2(2), 22-29.

Lowardi, R., \& Abdi, M. (2021). Pengaruh Pandemi COVID-19 terhadap Kinerja dan Kondisi Keuangan Perusahaan Publik Sektor Properti. Jurnal Manajerial dan Kewirausahaan, 3(2), 463-470.

Martalina, F. (2021). Analisis Kinerja Keuangan dan Strategi Keuangan UMKM di Kota Padang Pada Masa Pandemi COVID-19 (Doctoral dissertation, Universitas Andalas).

Muhari, S. (2021). Kinerja Jakarta Islamic index di masa Pandemi COVID-19 tahun 2020. Al- Mizan: Jurnal Hukum dan Ekonomi Islam, 5(1), 60-76.

Muslich, M. (2013). Manajemen Keuangan Modern. Penerbit Bumi Aksara, Jakarta.

Purnamasari, R., Abbas, A., \& Firana, Y. (2020). Analyzing the Company's Work Environment Within the Task Complexity.
Almana: Jurnal Manajemen dan Bisnis, 4(2), 230-236.

Riyanto. (2011). Dasar-dasar Pembelanjaan Perusahaan, Edisi Keempat, Yogyakarta: BPFE-Yogyakarta.

Sullivan, V.S., \& Widoatmodjo, S. (2021). Kinerja Keuangan Bank Sebelum dan Selama Pandemi COVID-19. Jurnal Manajerial dan Kewirausahaan, 3(1), 257266.

Yuliana, L. (2020). Dampak Kondisi Pandemi di Indonesia terhadap Trend Penjualan (Studi Kasus pada PD. Sumber Jaya Aluminium). JRB-Jurnal Riset Bisnis, 4(1), 27-38. 